\title{
Sustainable landscape management in the Vilhelmina Model Forest, Sweden
}

\author{
by Johan Svensson ${ }^{1,2}$, Per Sandström¹ ${ }^{1}$ Camilla Sandström ${ }^{3}$, Leif Jougda ${ }^{4}$ and Karin Baer ${ }^{5}$
}

\begin{abstract}
The aim of this paper is to outline current foundations for sustainable landscape management in the Vilhelmina Model Forest, northwest Sweden. A case study revealed that the remaining patches of undisturbed or less disturbed boreal forest ecosystems comprise multiple values and, thus, constitute the basis for landscape planning. By identifying these patches, it is also possible to construct a spatial planning infrastructure for implementing sustainable management and land use. A more comprehensive toolbox needs to be developed, however, including monitoring and inventory schemes for relevant biophysical and socio-economic data, better temporal resolution for cause and effect analyses, and functioning scale-flexible planning and governance instruments.
\end{abstract}

Key words: biodiversity, continuity forests, fragmentation, landscape planning, multi objective forestry, SFM, sustainable forest management, woodland key habitats

\section{RÉSUMÉ}

Lobjectif de cet article est de présenter les fondations actuels de l'aménagement durable du paysage de la Forêt Modèle de Vilhelmina, dans le nord-ouest de la Suède. Une étude de cas a révélé que les parcelles qui demeurent intactes et qui sont moins touchées dans les écosystèmes forestiers boréaux comportent de nombreux valeurs et, ainsi, constituent le fondement de la planification du paysage. En identifiant ces parcelles, il est également possible de construire une infrastructure de planification spatiale pour la mise en œuvre de l'aménagement durable et de l'utilisation des terres. Toutefois, on doit élaborer une trousse d'outil plus exhaustive, notamment des plans de surveillance et d'inventaire pour les données biophysiques et socioéconomiques pertinentes, une meilleure résolution temporelle pour les analyses des causes et des effets, et des instruments fonctionnels de planification et de gouvernance qui peuvent s’adapter à des échelles variables.

Mots clés : biodiversité, forêts de continuité, fragmentation, planification du paysage, foresterie multi objectif, aménagement durable des forêts, boisés des habitats essentiels

\section{Introduction and Scope}

It is evident that the complex nature and function of landscapes (Balée 1998, Council of Europe 2006) has to be regarded in any form of landscape planning that acknowledges the concept of sustainability. Accordingly, spatial as well as temporal perspectives on landscape configuration and land use have to be applied. This is particularly true under changing premises caused by climate change, new land use policies or changing demands on natural resources. From a biophysical point of view, the landscape is a continuum of land cover type, (e.g., forest, agriculture land, wetlands, water bodies, built-up infrastructure) and the transitions between them. The current land cover type or land use on any point in a landscape is a temporary phase that will change over time in response to natural changes or anthropogenic influence.

With reference to sustainable forest management (SFM; Andersson et al. 2005, Duinker 2011), a trend towards sustainable landscape management (SLM) applications is evident in landscape-oriented concepts such as Model Forests (Besseau et al. 2007), UNESCO MAB (UNESCO 1997) and
LTER sites (Long Term Ecological Research; Haberl et al. 2006). It can thus be understood that forests and all other land cover types in a landscape are regarded having the SFM concept otherwise not disputed or altered. This approach makes it possible to include all the terrestrial and aquatic biophysical components of the landscape as well as the natural changes and interaction by communities and institutions. The SLM approach can also be implemented for more specific components or aspects of the landscape such as biodiversity where biodiversity per se and the processes affecting biodiversity can be considered across land cover types and not specifically, for example, for forests. The implementation in practice of SLM is a planning exercise where different land use interests are combined and balanced in a spatiotemporal context across the biophysical and geographical extension of the focal landscape. Much has been declared about sustainable development and sustainability (Angelstam et al. 2004) but still very few good examples and results can be seen at the landscape level (Loikkanen et al. 1999, Duinker 2011).

The concept of biodiversity is central in landscape plan-

\footnotetext{
${ }^{1}$ Swedish University of Agricultural Sciences, Department of Forest Resource Management, 90183 Umeå, Sweden.

${ }^{2}$ Corresponding author. E-mail: johan.svensson@slu.se.

${ }^{3}$ Umeå University, Department of Political Science, Umeå, Sweden.

${ }^{4}$ Swedish Forest Agency, Vilhelmina, Sweden.

${ }^{5}$ Vilhelmina North Reindeer Herding Community, Dikanäs, Sweden.
} 
ning, both from strategic and operational points of view. It has evolved as an issue on the global agenda of environmental concern with the 2010 International Year of Biodiversity as a major event (Larigauderie and Mooney 2010). From a focus on systematic and taxonomy in the 1970s and 1980s, the biodiversity concept currently has an evident linkage to ecosystem functioning, ecosystem services and human well-being, but also to economic and environmental consequences of decision-making and other practical implementation processes (Dirzo and Loreau 2005). Biodiversity is also a central component of both the Ecosystem Approach and the concept of SFM (MCPFE 2006). Much effort is now being directed to extract basic biodiversity data and information to be put into strategic policy-making processes as well as into practical landscape planning modules (Ståhl et al. 2011). Holistic approaches and synergies are needed to adequately approach these complex issues at a landscape level (Angelstam et al. 2004).

As global changes are predicted, the concept of sustainability needs to be adjustable, allowing (a) top-down input to secure territorial overview; (b) bottom-up input to secure local participation; (c) networking and sharing of relevant knowledge; and (d) balancing the different dimensions of sustainability in land use planning. Currently, there is a need for functional examples of sustainable development producing sustainability in practice, locally, and in real landscapes. To achieve this we need a range of innovative and valid indicators, criteria, thresholds, tools and approaches for dissemination and for scaling up good examples. We also need the infrastructure and communication routines to deliver the process and its outcomes in an understandable and appreciated way to land use actors, decision-makers and the public (Sandström et al. 2003, Olsson et al. 2004).
With reference to SLM, this article describes some current and important landscape management and planning premises in the Vilhelmina Model Forest, northwest Sweden. The emphasis is on the forested part of the landscape and, in particular, on the spatiotemporal fragmentation of natural coniferous forests and the consequences of this process on landscape planning. Remaining natural forests that have not been subject to clearcutting represent a critical pool for biodiversity in boreal coniferous landscapes (Brandt 2009, Villard and Jonsson 2009). The impact of forestry is a key landscape influence mechanism that affects not only biodiversity and nature conservation premises, but also other important aspects of landscape use, needs and interests. Moreover, the impacts of forest management activities are not only confined to forested areas but also strongly influence other landscape planning fundaments in other land cover types, such as barren mountains, wetlands and water bodies, and hence the holistic landscape planning fundaments.

\section{The Vilhelmina Model Forest Landscape}

The Vilhelmina Model Forest covers about 870000 ha of northwest Swedish boreal forest landscape transitioning into the alpine environments of the Scandinavian Mountain Range and the border to Norway (Fig. 1). The main landscape structures of the Model Forest area are two river valleys-the Ångermanälven River that originates in the Kultsjödalen Valley within the Model Forest area and flows some $450 \mathrm{~km}$ southeastwards to the Gulf of Bothnia, and the Vojmsjödalen Valley that connects to Ångermanälven in the southern part of the area close to the city of Vilhelmina. Along their flow the rivers form a number of lakes that also function as water reservoirs for hydro-electrical power stations. Mountains frame the river valleys at their northwest end and along both

\section{Russia and Northern Europe}

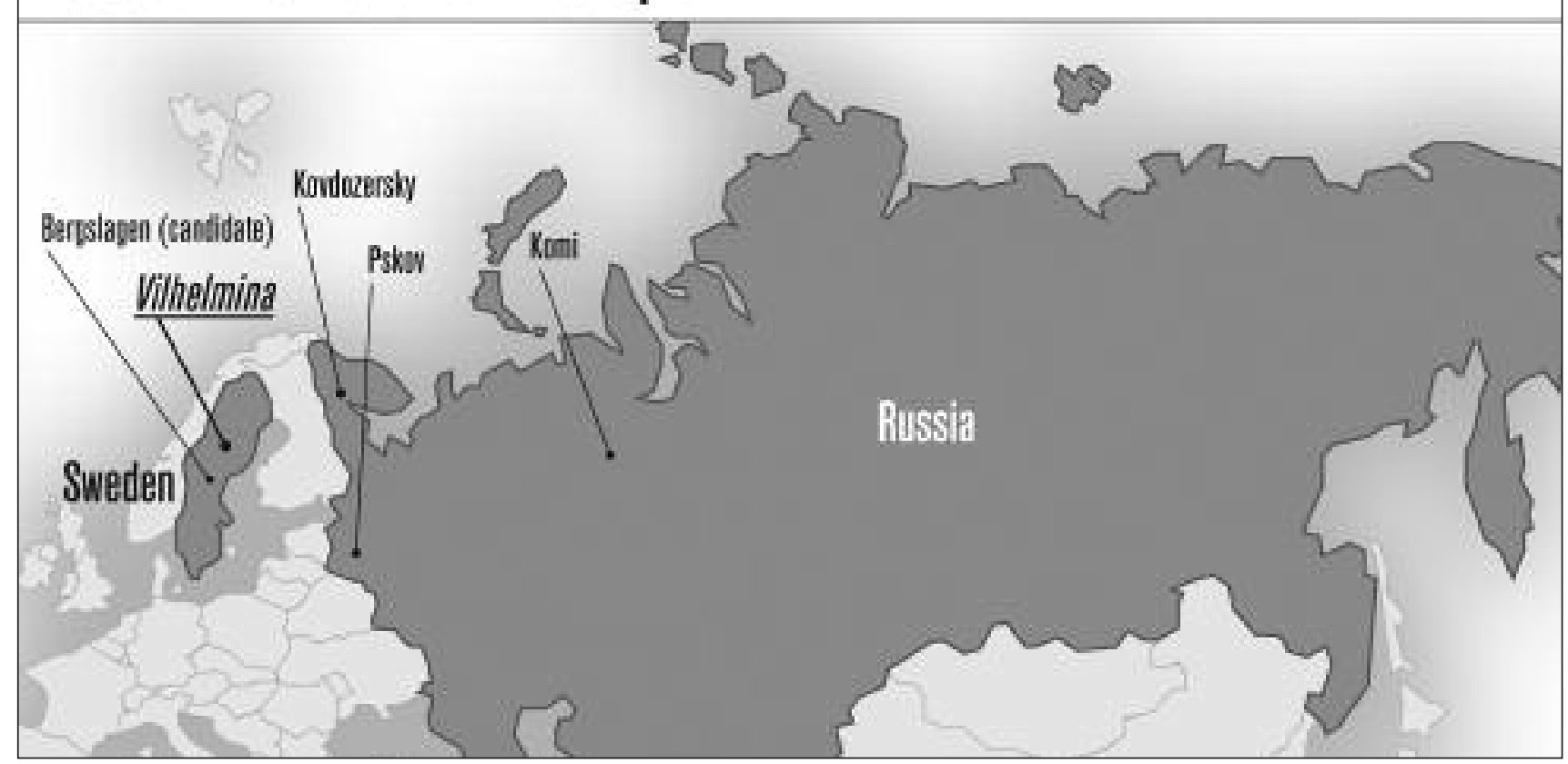

Fig. 1. Location of the Vilhelmina Model Forest. 
sides of the valleys. Peatlands and mires are formed both on lowlands and on higher altitudes in the mountains.

About 530000 ha are forested land. The area is a typical coniferous-dominated landscape, variable in its topography from about 340 metres above sea level (m.a.s.l.) up to about 1600 m.a.s.l. in the mountains (Fig. 2). There is a variety of tree species, mainly Norway spruce (Picea abies [L.] Karst.), Scots pine (Pinus sylvestris L.), aspen (Populus tremula L.) and birch (Betula pubescens Ehrh. and Betula pendula Roth). The amount of old, natural forest increases westwards in the area and significant parts of the foothills forest still exhibit natural or close to natural conditions. The absolute majority of the nature reserves and other protected areas is located in the foothills zone. Currently there are 180000 ha of protected areas within the Vilhelmina Model Forest. The alpine tree line is formed by mountain birch (Betula pubescens subsp. tortuosa [Ledeb.] Nyman) at about 800 m.a.s.l. Some 350000 ha are classified as productive forest land and are used primarily for timber production. The ownership structure is typical for northwest Sweden, with the majority owned by private, family owners $(36 \%)$, private forest companies $(22 \%)$ and the state forest company (29\%).

The landscape is sparsely populated with about 7500 inhabitants, equal to a population density of less than one person per $\mathrm{km}^{2}$, about half of whom live in the city of Vilhelmina and its closest surroundings. Despite its remote location and low human population density, the landscape is under active land use and has been so for a long time. In the first half of the $20^{\text {th }}$ century and earlier, traditional reindeer (Rangifer tarandus L.) herding by indigenous Sami communities and small scale-farming were the main types of land uses. Currently, and during the most recent past, the main land uses are forestry and reindeer-herding together with a quite extensive development of hydro-electrical power stations and a developing tourism sector. Also, mining has been significant in parts of the area with the Stekenjokk copper mine in the alpine region in the western part of Model Forest. The mine was established in 1976 and was shut down in 1988. A current trend is towards an elevated interest in additional development of hydro-electrical power stations as well as establishment of wind mills, mining and tourism, whereas the forest industry is a stable or decreasing sector.

\section{Forests - Conflicting Interests}

Forests have always played an important economic role in Sweden but are now of increasing importance not only for forest production and nature conservation but also for recreation and other non-timber aspects. The view of the land as a common pool for various needs and interests (i.e., for ecosystem services), sometimes irrespective of land ownership and sometimes strongly linked to ownership, makes the issue of sustainable landscape management critically challenging. Almost half of the inhabitants in the Vilhelmina Municipality own a forest property. Forestry and the forest industry are vital components of the local economy, with about 200 people employed in the sector.

An overarching landscape planning issue is how to combine reindeer husbandry with other land use interests, mainly forestry. This is also the main issue on the Vilhelmina Model Forest agenda (Svensson et al. 2004). The land in the northern part of Sweden is a common pool resource where indige- nous Sami people have the right to herd reindeer, regardless of ownership. A large proportion of the land used for reindeer herding is also used for forest production. Thus, forest managers and reindeer herders comprise two groups of actors who, to a large extent, use the same land but for different purposes. This multiple use of the forest resources in the northern parts of Sweden is sometimes a source of conflict (Sandström and Widmark 2007). About 100 of the indigenous Sami people are organized in two reindeer herding communities, Vilhelmina North and Vilhelmina South Reindeer Herding Communities.

Under the "right of public access" in Sweden, everyone is entitled to cross, at least on foot, all land and remain there temporarily. It is a public right that can be traced back to laws and customs of the Middle Ages and that imposes great demands for care and consideration toward nature. Picking berries and mushrooms is allowed under the right of public access and is still of importance to many private households but is also a growing industrial sector with professional berry and mushroom pickers that are employed by private companies. Hence, there is a risk that the economic interests of private land ownership conflict with the interests of the broader public or companies, inevitably leading to rivaling claims to the use of the forest and the landscape (Sandström et al. 2006). Hunting of small and big game is also an important activity for local inhabitants and as a business activity. Hunting is not included in the right of public access, however.

\section{Forests - A Central Biodiversity Pool and a Founda- tion for Landscape Planning}

Modern forestry operations cause degradation of natural forest landscapes with associated biodiversity loss (Berglund and Jonsson 2005). This has stimulated a search for undisturbed or lesser-disturbed forest landscapes to identify biodiversity hotspots for nature conservation purposes, provide references for studies on ecosystem processes and consequences of human impact, and provide essential background information for land use policy and decision-making.

A certain focus has been brought to the importance of landscape continuity and of natural disturbances as key natural mechanism to maintain ecosystem processes and hence natural biodiversity (Nordén and Appelqvist 2001, Fritz et al. 2008). Continuity can be defined as a spatiotemporal unbroken availability of forest habitats. At the site level (i.e., local continuity), continuity implies that trees and other forest structures (e.g., dead wood, several tree ages and sizes, gaps) should be present for several tree generations within a defined area. At the landscape level (i.e., landscape continuity), forest continuity can be defined as the uninterrupted supply of forest habitat patches in the spatiotemporal context of the landscape (Hanski 1999).

Historically, the boreal landscape of northern Sweden consisted of a mix of conifer-dominated forests of all ages (Linder and Östlund 1998). Episodes of natural disturbance occurred with loss of forest cover at various spatial scales and with varying frequency. Proportions of undisturbed forests were left as refugia and re-colonization areas for species and processes that depend on ecosystem continuity. With industrial forestry as the main disturbance agent, there is currently much concern about the decline in the amount of continuity forests (Cedergren 2008). From a land use and landscape 
planning perspective, the occurrence of continuity forest, especially clustered in larger patches and in intact networks, plays a central role in nature conservation strategies (Lindenmayer and Franklin 2002, Villard and Jonsson 2009).

From a wider perspective, however, the remaining natural forests accommodate other values in addition to biodiversity values (Axelsson et al. 2007). For forest management, the remaining natural forest provides a good source of timber, pulpwood and bioenergy, for the tourist sector they represent attractive visitor spots and hunting land, and, for the reindeer herders, forests provide good grazing land and areas for moving reindeer. Hence, the remaining natural forests are central components in sustainable landscape planning and management in the Model Forest, representing nodes and hot spots for multiple values. They provide the principle for the sustainable landscape planning process in Vilhelmina Model Forest.

\section{A Case Study on Fragmentation of Natural Forests}

Widespread use of industrial forestry in the Model Forest area occurred quite late. Records from the Swedish Forest Agency-the State forest authority in Sweden-indicate that the first regular clearcutting took place in 1958. It can be assumed that the forests at that time were affected by different types, and various intensity of, selective cutting. It also needs to be noted that prior to 1958 the Swedish State forest company exercised more intensive forestry in northwest Sweden but without regular application procedures to the Swedish Forest Agency. This non-application rule for the State forest company was in effect up to the 1971 Forestry Act. In a landscape context, however, it can be assumed that the forested part of the Model Forest held intact forest characteristics (i.e., extensive natural or semi-natural forests) to a significant degree up to the 1950s.

In an ongoing study encompassing the southeastern half of the Model Forest $\left(4160 \mathrm{~km}^{2}\right)$, we focus on the trends of decline and fragmentation of the forest landscape by clearcutting. We use a time series of satellite images to create a chronosequence and to identify areas that are not affected by clearcutting. By retrospective analysis of 15 Landsat images dating from 1973, we have identified non-clearcut patches of forests and estimated the proportion of remaining natural forest cover with supplementary $\mathrm{kNN}$-analysis (kNN Sweden; Reese et al. 2005) and data from the National Forest Inventory (Fridman and Walheim 2000). Through change detection we have identified and dated each clearcutting event, which has allowed us to calculate cutting rates at the landscape level, trace the decline in amount of remaining forest patches, and evaluate their spatial distribution, connectivity and fragmentation in the landscape.

Some results in this study are illustrated in Fig. 3, indicating that only fragments of the natural forest landscape remain. Using 1958 as the base year with $66 \%$ of the total study area as forest land ( $0 \%$ loss) there is a $33 \%$ loss in 1973 , a $45 \%$ loss in 1986, and a 63\% loss in 2005 .

It should be noted that northwest Sweden, generally, is a key area for nature conservation strategies at the national level because of the substantial degree of remaining natural forests. Our current results in this case study do not, however, support that view. It can be concluded that significant impact has occurred over large areas and that remaining natural forests only remain as fragmented patches.
Further west in the foothill forest of the region, however, the situation is less drastic with respect to the impact of clearcutting. It is possible to identify traces of a timber frontier where industrial forestry activity has not yet reached that area. One important reason for this is that selective cutting (e.g., continuous thinning) has been quite common in the area. According to Swedish Forest Agency records from 1971 to 1991 for the forest district around Vilhelmina, selective cutting has been used on about the same total area as clearcutting. Incentives for this less-intensive forest management include a large proportion of private and community ownership, tradition and willingness to apply other methods than ordinary clearcutting, scarification and planting.

\section{Lessons Learned for Sustainable Landscape Man- agement in the Vilhelmina Model Forest}

Some 50 years of clearcut-oriented forestry has had a significant impact on the landscape in the southeastern part of the Model Forest. In a landscape planning context we can conclude that multiple interests are directed towards the remaining patches and fragments of natural forests and, consequently, that these represent critical hubs and networks. Planning for nature conservation is challenging given the objective to provide good opportunities for conserving biodiversity and allowing threatened species to maintain vital populations and sustain natural migration and other ecological processes. Fig. 4 illustrates the distribution of nature reserves in and around the study area. It is evident that the majority of the land does not have natural values that are strong enough for protection according to the current conservation strategies. The national Woodland Key Habitat (Gustafsson et al. 1999) inventory has, however, documented a large number of Woodland Key Habitats that are not within existing protected areas. It is obvious that many Woodland Key Habitats are situated in, or very close to, the remaining natural forests. It should be noted that the Woodland Key Habitats in Fig. 4 include both natural forest habitats and other habitats such as creeks and ravines.

Planning for reindeer herding may seem even more challenging, given that forest management activities have strongly affected natural grazing habitats and caused a disruption in the natural migration routes for the reindeer as they annually move across the Model Forest from the summer grazing land in the mountains to the winter grazing land in the forested lowlands in the east. Natural forests normally hold epiphytic tree-lichens and ground-living lichens that are a critical food resource for the reindeer. Clearcutting and scarification result in severe depletion of this resource.

It is evident that implementing sustainable landscape management in the Model Forest requires a much more holistic toolbox than available today, including, for example:

Monitoring schemes that provide long-term series of accurate and representative data that are applicable at the landscape level and for different land cover types. Monitoring in Sweden is currently conducted at both the national and regional (county) levels. Regional-level monitoring is commonly oriented towards a specific type of data (e.g., on arctic fox (Alopex lagopus L.) population dynamics), whereas national monitoring through the National Forest Inventory (Fridman and Walheim 2000) and the NILS program (National Inventory of Landscapes in Sweden; Ståhl et al. 


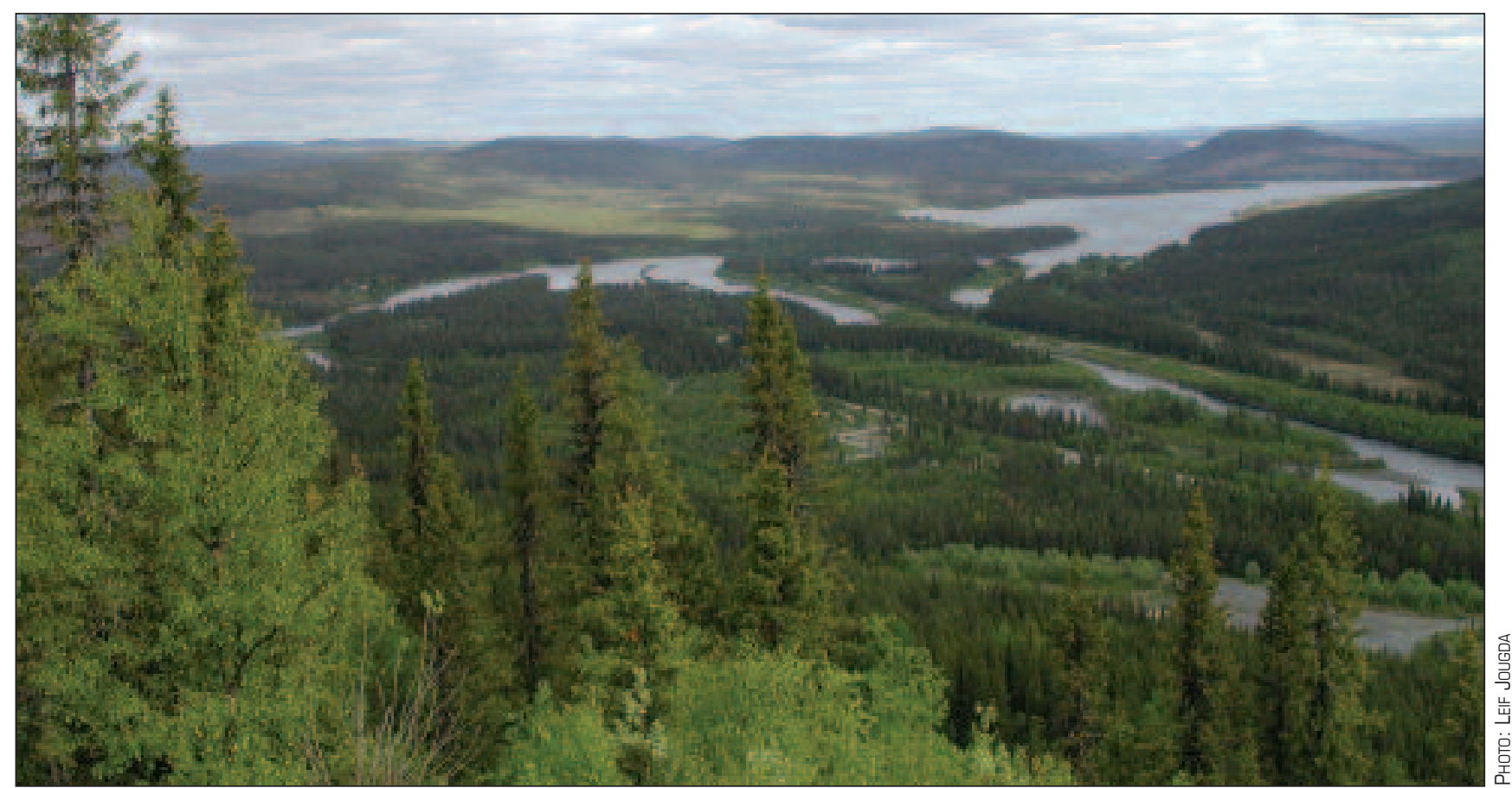

Fig. 2. Vilhelmina Model Forest landscape. The photo is taken at a point just west of and overlooking the study area illustrated in Fig. 3.

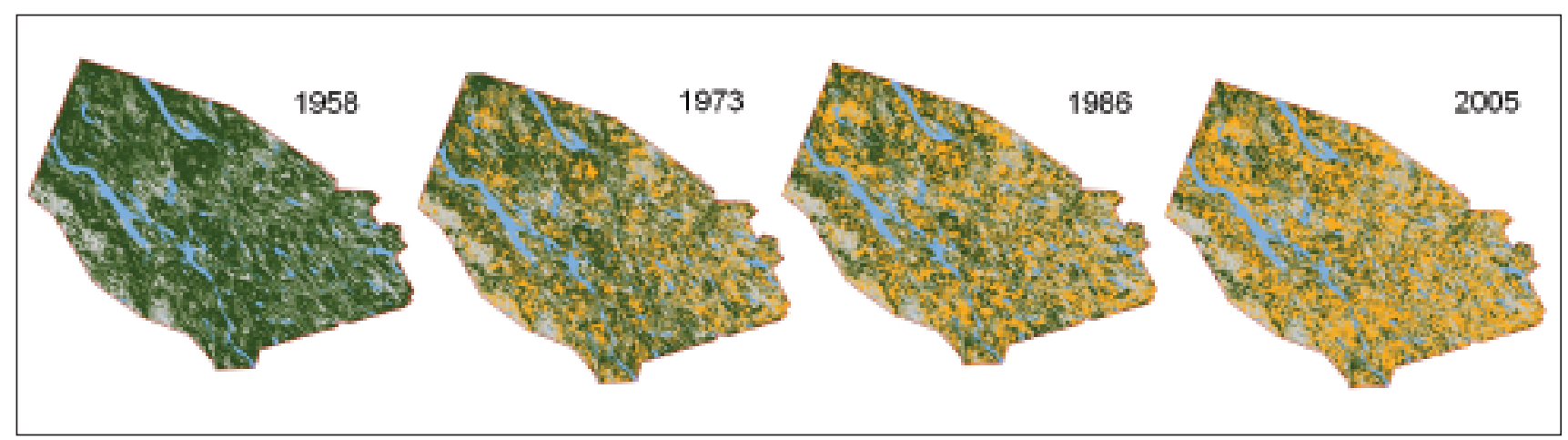

Fig. 3. 1958 to 2005 chronosequence of clearcuts in the southeastern part of VMF. Green = forest land; Orange = clearcut; Blue = water bodies; Grey = wetlands, barren mountains and other naturally non-forested areas. The mapped area is $4160 \mathrm{~km}$ ?

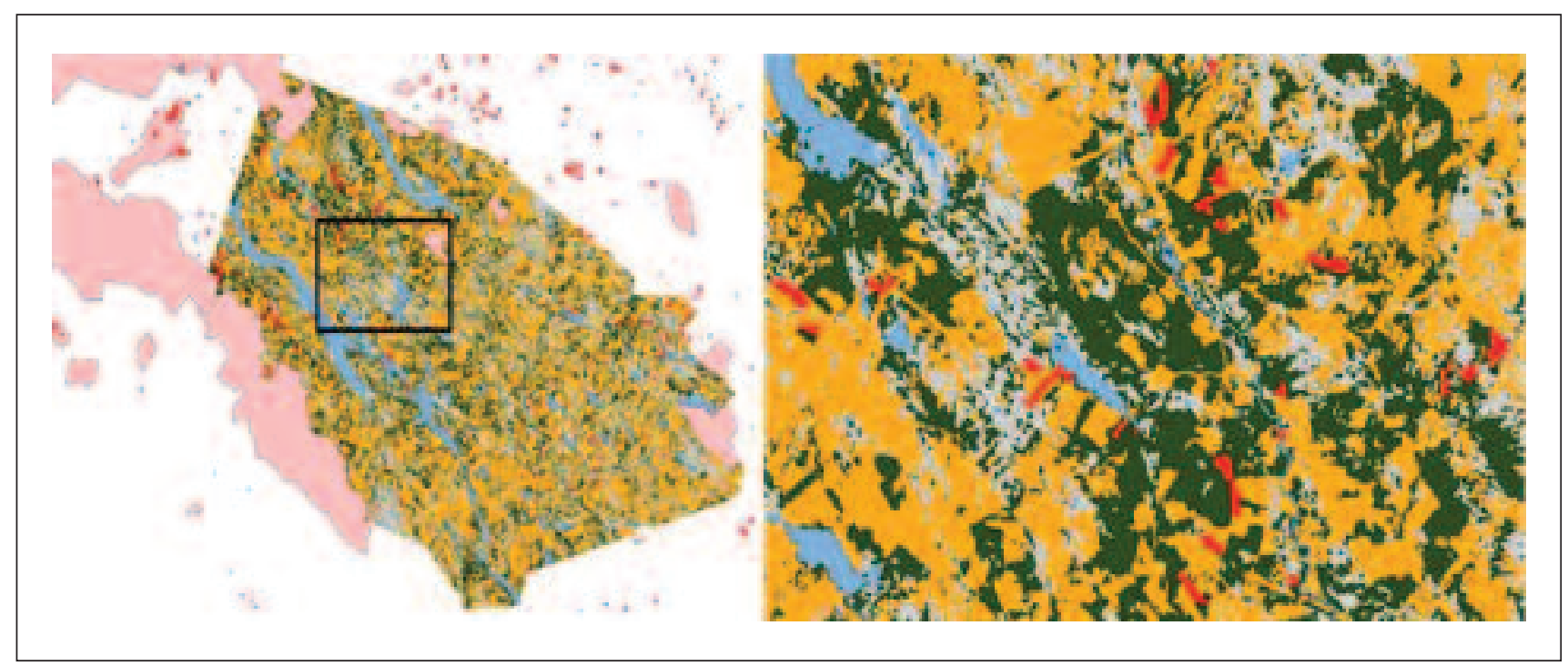

Fig. 4. Protected areas (pink) and Woodland Key Habitats (red) in and in the surroundings of the study area. 
2011) has a too-low spatial resolution and limited or nonexisting linkage to landscape planning. Limitations in the linkage between biophysical monitoring and landscape planning, as well as with other processes such as decisionmaking procedures, seem to be a general problem (Svensson et al. 2009).

Improved specific inventories for areas with high nature conservation values (e.g., Woodland Key Habitats as illustrated in Fig. 4) specifically concerning the delineation of the Woodland Key Habitats and the representativeness in the whole landscape. In Sweden, the Woodland Key Habitats inventory is developed for a fragmented landscape where borders to nonWoodland Key Habitats are obvious, and conducted as a random sampling scheme with limited comparison options between the selected point and other points in the landscape. This limits the possibilities to implement conservation strategies based on Woodland Key Habitats for a more homogeneous coniferous landscape where new forest is generated, and to create landscape level models and scenarios for multi-objective land use approaches (Laita et al. 2010). A current approach in Swedish nature conservation policy is to identify Biological Value Regions (Triumf 2008) - areas with higher concentrations of Woodland Key Habitats than surrounding areas. The approach is promising but with limited applicability because of the lack of representativeness across the landscape.

Temporal resolution in analyses to be able to predict consequences of different land use policies on the landscape. Historical data are necessary to be able to correctly interpret current status (e.g., of the presence of red-listed species) as background information for planning strategies. In particular, under a climate change scenario, empirically derived cause and effect analyses are central to evaluating ecosystem response and processes (Metzger 2008). In this particular case it is of utmost interest to be able to learn from the situation in the southeastern half of the Model Forest for the ongoing process of land use in the northwestern and less impacted foothills landscape of the Model Forest. This is valid not only for forestry but also for other major land use activities, such as mining and development of wind mills for production of electricity.

A scale-flexible approach that allows analyses and planning on various geographical scales (point, stand, estate, landscape) to be able to put each focal point in its landscape context. Landscape planning is complex not only because of the geographical scale but also with respect to multiple demands and, in the case of Sweden, because of a multitude of different land owners with different capacities and interests.

Governance and management strategies that promote multiple objectives in forestry (e.g., continuous cover forestry; Mason 2003) that target both forest production and nature conservation objectives simultaneously. In Sweden, as in other countries, there is a tendency to divide the landscape into compartments where a specific objective is in focus such as a nature reserve for nature conservation or a forest management unit for gross pulp production. Fig. 3 illustrates a situation where such a compartmentalized landscape is not far from being realized. In a climate change situation or when new natural resource demands and markets are developing and, hence, future prospects are less predictable, it is risky to dedicate areas specifically for a single purpose. Strategies that more strongly promote multi-objective approaches require, however, better flexibility in employing, for example, nature conservation tools such as nature reserves and biotope protection areas. Nature conservation agreements have been applied in Sweden since the mid-1990s. These agreements include economic compensation to landowners for increased nature conservation consideration over a limited period of time. A similar system is under way for greater consideration towards reindeer herding than can be imposed through legal criteria.

Clear administrative responsibilities and more harmonized policies between pan-national, national, regional (county) and local (municipality) levels. The administration of the forest ecosystems lies primarily with the Swedish Forest Agency which monitors the legal requirements, provides advice on forest-related matters and services to the forest industry, supports nature conservation efforts, conducts inventories and supervises compliance with the Forest Act. The County Administrative Boards have a more general jurisdiction over nature conservation with a decision-making mandate on nature reserves as well as on many other major land use issues. The Municipality Boards have the landscape planning mandate at the local level, however. This is a complex governance situation that does not promote efficient and transparent landscape management processes. In the Model Forest, for instance, there is a current situation where the County Administrative Board promotes the development of a National Park in one of the nature reserves (Blaikfjället Nature Reserve, located along the southwest edge of the study area, Fig. 4), whereas the Municipality Board so far is reluctant to consider this development. As well, pan-national policies such as the Nature 2000 network, have limited practical applicability on top of the existing administrative frameworks.

\section{Conclusions}

Sustainable landscape management takes into account whole landscapes with the existing biophysical and socio-economic premises. This is challenging. The multifunctional use of the landscapes often creates classic collective action dilemmas such as industrial forestry versus nature conservation or versus reindeer management. To be able to take into account land use policies and the different interests represented by the different stakeholders that share an interest in the landscape, there is a need to develop better strategies and tools that are able balance these multiple interests. In this paper, we focus on the impact of forestry in relation to other major land use aspects. It is clear that despite good data input into planning processes, actual land use planning that takes into account ongoing forest management, nature conservation, recreation, reindeer herding and other land base interests is difficult to implement in practice. Ongoing work in the Vilhelmina Model Forest is promising, however. The Model Forest offers an arena where different interests can meet and potentially merge into concrete landscape planning and sustainable landscape management, and ultimately promote holistic solutions beyond local boundaries. 


\section{References}

Andersson, F., P. Angelstam, K.-H. Feger, H. Hasenauer, N. Kräuchi, A. Mårell, G. Matteucci, U. Schneider and P. Tabbush (eds.). 2005. A research strategy for sustainable forest management in Europe. Technical Report 5, COST Action E25. ECOFOR, Paris. $166 \mathrm{p}$.

Angelstam, P., R. Persson and R. Schlaepfer. 2004. The sustainable forest management vision and biodiversity - barriers and bridges for implementation in actual landscapes. In P. Angelstam, M. DönzBreuss and J.-M. Roberge (eds.). Targets and tools for the maintenance of forest biodiversity. Ecological Bulletins 51: 29-49.

Axelsson, R., P. Angelstam and J. Svensson. 2007. Natural forest and cultural woodland with continuous tree cover in Sweden: How much remains and how is it managed? Scandinavian Journal of Forest Research 22: 545-558.

Balée, W. 1998. Historical Ecology: Premises and Postulates. In W. Balée (ed.). Advances in Historical Ecology. Columbia University Press, New York.

Berglund, H. and B.G. Jonsson. 2005. Verifying an Extinction Debt among Lichens and Fungi in Northern Swedish Boreal Forests. Conservation Biology 19: 338-348.

Besseau, P., W. Alvardo, P. Daloos, L. Jones, C. Jum, C. Mooney, J. Svensson, G. Telitsyn and L. Wagan. 2007. Creating vibrant, broadbased partnerships for SFM - the model forest experience. In Y.C. Dubé and F. Schmithüsen. Cross-sectoral Policy Developments in Forestry. CABI.

Brandt, J.P. 2009. The extent of the North American boreal zone. Environ. Rev. 17: 101-161.

Council of Europe. 2006. Landscape and sustainable development: challenges of the European Landscape Convention. Council of Europe Publishing.

Cedergren J. 2008. Kontinuitetsskogar och hyggesfritt skogsbruk. MEDDELANDE 1 - 2008. Skogsstyrelsen, Jönköping. [Continuous cover forests and continuous cover forestry. Report 1. Swedish Forest Agency, Jönköping, Sweden].

Dirzo, R. and M. Loreau. 2005. Biodiversity science evolves. Science 310: 943.

Duinker, P.N. 2011. Advancing the cause? Contributions of criteria and indicators to sustainable forest management in Canada. The Forestry Chronicle 87(4): 488-493.

Fridman, J. and M. Walheim. 2000. Amount, structure and dynamics of dead wood on managed forest land in Sweden. Forest Ecology and Management 131: 23-26.

Fritz, Ö. L. Gustafsson and K. Larsson. 2008. Does forest continuity matter in conservation? A study of epiphytic lichens and bryophytes in beech forests in southern Sweden. Biological Conservation 141:655-668.

Gustafsson, L., J de Jong and M. Norén. 1999. Evaluation of Swedish woodland key habitats using red-listed bryophytes and lichens. Biodiversity and Conservation 8: 1101-1114.

Haberl, H. et al. 2006. From LTER to LTSER: conceptualizing the socioeconomic dimension of long-term socioecological research. Ecology and Society 11.

Hanski, I. 1999. Habitat connectivity, habitat continuity, and metapopulations in dynamic landscapes. Oikos 87: 209-219.

Laita, A., M. Mönkkönen and J.S. Kotiaho. 2010. Woodland key habitats evaluated as part of a functional reserve network. Biological Conservation 143: 1212-1227.

Larigauderie, A. and H. A. Mooney. 2010. The international year of biodiversity: an opportunity to strengthen the science-policy interface for biodiversity and ecosystem services. Current Opinion in Environmental Sustainability 2: 1-2.

Lindenmayer, D.B. and J.F. Franklin. 2002. Conserving forest biodiversity: A comprehensive multiscaled approach. Island Press. xiii+351 pp.
Linder, P. and L. Östlund. 1998 Structural Changes In Three MidBoreal Swedish Woodland Landscapes, 1885-1996. Biological Conservation 85: 9-19.

Loikkanen, T., T. Simojoki and P. Wallenius. 1999. Participatory approach to natural resource management. A guide book. Forest and Park Service, Metsähallitus, Vantaa, Finland. 96 p.

Mason, W. L. 2003. Continuous cover forestry: Developing close to nature forest management in conifer plantations in upland Britain. Scottish Forestry 57: 141-149.

Metzger, J.P. 2008. Landscape ecology: perspectives based on the 2007 IALE world congress. Landscape Ecology 23: 501-504.

[MCPFE] Ministerial Conference on the Protection of Forests in Europe. 2006. Pan-European biological and landscape diversity strategy. Joint position of the MCPFE and the EfE/PEBLDS on the pan-European understanding of the linkage between the ecosystem approach and sustainable forest management. Geneva - Warsaw.

Nordén B. and T. Appelqvist. 2001. Conceptual Problems of Ecological Continuity and its Bioindicators. Biodiversity and Conservation 10: 779-791.

Olsson, P., C. Folke and T. Hahn. 2004. Social-ecological transformation for ecosystem management: the development of adaptive comanagement of a wetland landscape in southern Sweden. Ecology and Society 9(4): 2.

Reese, H., T. Granqvist-Pahlén, M. Egberth, M. Nilsson and H. Olsson. 2005. Automated estimation of forest parameters for Sweden using Landsat data and the $\mathrm{kNN}$ algorithm. Conference proceedings, $31^{\text {st }}$ International Symposium on Remote Sensing of Environment, St. Petersburg.

Sandström, C., J. Moen, C. Widmark and Ö. Danell. 2006. Progressing toward Co-management through collaborative learning forestry and reindeer husbandry in dialogue, International Journal of Biodiversity, Science and Management 2(4): 326-333.

Sandström, C. and C. Widmark. 2007. Stakeholders' perceptions of consultations as tools for co-management - A case study of the forestry and reindeer herding sectors in northern Sweden, Forest Policy and Economics. Doi:10.1016/j.forpol.2007.02.001.

Sandström, P. et al. 2003. Conflict resolution by participatory management: remote sensing and GIS as tools for communication landuse needs for reindeer herding in northern Sweden. Ambio 32(8): 557-567.

Ståhl, G. et al. 2011. National Inventory of Landscapes in Sweden (NILS) - Scope, design, and experiences from establishing a multiscale biodiversity monitoring system. Ecological Monitoring and Assessment 173: 579-595.

Svensson, J., A. Allard, P. Christensen, Å. Eriksson, P.-A. Esseen, A. Glimskär and S. Sandring. 2009. Landscape biodiversity monitoring in the Swedish NILS program. Proceedings XIII World Forestry Congress. Buenos Aires, Argentina, 18-23 October 2009. 8 p.

Svensson, J., C. Fries and L. Jougda. 2004. Synthesis of the Model Forest concept and its application to Vilhelmina Model Forest and Barents Model Forest Network. Swedish Forest Agency, Report 6. Jönköping, Sweden.

Triumf, H. 2008. Landscape planning and improvements of connectivity within biological value regions in the County of Västerbotten. Masters thesis. Department of Forest Ecology and Management, SLU, report 2008:29. $60 \mathrm{p}$.

UNESCO. 1997. The world network of Biosphere reserves. UNESCO Courier 50(5): 36-37.

Villard, M.-A. and B.G. Jonsson. 2009. Tolerance of focal species to forest management intensity as a guide in the development of conservation targets. Forest Ecology and Management 258: 142-145. 